\title{
A European Perspective on the G20 and the BRICS 1
}

\author{
J. Wouters, S. Van Kerckhoven
}

\begin{abstract}
Jan Wouters - PhD, Jean Monnet Chair ad personam EU and Global Governance; Full Professor of International Law and International Organizations; Director of the Leuven Centre for Global Governance Studies and the Institute for International Law, KU Leuven; House De Dorlodot, Deberiotstraat 34 B-3000 Leuven, Belgium; E-mail: jan.wouters@ggs.kuleuven.be

Sven Van Kerckhoven - PhD, Assistant Professor; Head of the Business and Economics Department, Vesalius College/Vrije Universiteit Brussels; Associate Fellow, Leuven Centre for Global Governance Studies and the Faculty of Economics and Business, KU Leuven; Pleinlaan 5, 1050 Brussels, Belgium; E-mail: Sven.Van. Kerckhoven@vub.be
\end{abstract}

\begin{abstract}
This article considers how the European Union (EU), as the most developed regional organization and as one of the strongest global economic players, deals with the global summitry of club-like entities such as the Group of 20 (G20) and the BRICS grouping of Brazil, Russia, India, China and South Africa. The EU, the G20 and the BRICS share similar ambitions, namely addressing global (or regional) cross-border challenges by increasing cooperation and coordination at the international level. Even though the EU is a fond supporter of global decision-making bodies, the rise of these informal bodies challenges the EU's approach to global governance, which relies heavily on effective multilateralism supported by a rules-based approach. Because several of the BRICS and G20 members favour a more relationship-based approach focused on consensus and coordination, these bodies challenge the European approach . While a clear European strategy to deal with informal bodies is thus needed, a coherent and consistent approach is missing. This is evidenced by the lack of any reference to the BRICS and only a cursory reference to the G2O in the EU's 2016 global strategy, and by the fact that the EU currently has only bilateral strategic partnerships with most of the G20 and BRICS members. This article argues that, given the particular challenges these bodies pose and their remarkable rise in recent years, a fully fledged EU strategy towards the G2O and the BRICS should be developed.
\end{abstract}

Key words: EU; G20; BRICS; global governance

For citation: Wouters J., Van Kerckhoven S. (2018) A European Perspective on the G20 and the BRICS. International Organisations Research Journal, vol. 13, no 2, pp. 60-75 (in Russian and English). DOI: 10.17323/1996-7845-2018-02-04.

\section{Introduction: The Need for Cooperation}

The last decades of intense globalization have created new challenges and new opportunities for countries, companies and consumers. At the same time, globalization has also brought to the forefront the need for guidance and decision-making in order to deal with these new challenges and opportunities. Since countries and economies are more interdependent and linked than ever before, individual states are unable to provide effective governance in the era of globalization. Thus, globalization has put traditional state-based governance arrangements on shaky ground, as the ability of individual countries to solitarily address issues has greatly diminished.

${ }^{1}$ The editorial board received the article in February 2018. 
For example, Cooper [1968, p. 262, cited in Lake, 2006, p. 769] concludes that "[globalization] is prompting significant shifts in sites of political authority, upwards to newly empowered supranational institutions, downwards to revitalized regions, provinces and municipalities, and laterally to private corporations and non-governmental organizations that acquire public responsibilities." With the state struggling, the need for governance bodies to provide guidelines and rules for the conduct of (economic) transactions has never been more apparent.

The need for governance upwards from the state has resulted in a number of bodies that together have created a multilayered governance structure. First, several international organizations were founded in the aftermath of World War II, most importantly the United Nations (UN) and its "family" of specialized agencies that coordinate through the Economic and Social Council (ECOSOC), including the International Monetary Fund (IMF), the World Bank (WB), the World Health Organization (WHO) and the International Labour Organization (ILO). Second, certain initiatives have been taken at the regional level. Regional partnerships and collaborations are, in general, more likely to perform well due to more homogeneous preferences with regard to expected policy outcomes. The most integrated regional organization is the European Union (EU), where members have integrated as far as sharing a single market and a single currency (for the eurozone members). Other examples include the Association of Southeast Asian Nations (ASEAN) and the Caribbean Community (CARICOM). Third, some looser and more informal bodies have been established. There exists a vast variety of the latter type. This article pays particular attention to the club-like entities. These bodies are informal and characterized by the lack of a constituent instrument, formal voting mechanisms or legally binding decisions. Recent decades have witnessed the rise of several of these club-like bodies, such as the Group of 20 (G20) and the BRICS grouping of Brazil, Russia, India, China and South Africa (for an extensive overview and characterization, see Wouters and Van Kerckhoven [2017a]).

All of these governance bodies perform certain functions that could result in more welfare, both at the global and at the national level; they increase the number of interactions between participants, they provide a forum for bargaining and information transmission, they limit the transaction costs of conducting international business, they can punish participants that deviate from the cooperative outcome and they can deliver selective benefits to parties that behave cooperatively [Van Kerckhoven, Crombez, 2015].

This article asks how the EU, as the most developed regional organization and as one of the strongest global economic players, deals with global summitry of club-like entities such as the G20 and the BRICS. In doing so, we take into account the EU's approach to global governance based on the concept of effective multilateralism, considering in particular how it has been challenged by the rise of the G20 and the BRICS.

Section 2 discusses the rise of global cooperation and provides an overview of the most significant developments in the evolution of the EU, the G20 and the BRICS. It pays particular attention to the similar challenges these bodies have faced. Section 3 explores the relationship between the EU and the G20. Section 4 does the same with respect to the BRICS. Section 5 outlines how the G20 and the BRICS challenge the traditional EU approach to global affairs. Section 6 reviews the EU's current strategies and develops some recommendations for the EU with a view to a more strategic approach to the G20 and the BRICS. The article ends with a short conclusion.

This article builds on existing literature in the field and adds to this an in-depth investigation of recent sources and the 2016 EU Global Strategy on Foreign and Security Policy. While descriptive in nature, it aims to provide a critical reflection on the position of the EU with regards to the rising importance of informal bodies such as the G20 and the BRICS. 


\section{The Rise of Cooperation}

Cooperation can help to address the challenges arising in a global environment. At the same time, cooperation ensures that certain benefits can be attained. As a result, international cooperation has resulted in the establishment of a wide variety of institutions in recent decades. This section focuses on two of the most peculiar changes in the development of international organizations, namely the fast and deep integration of the EU and the rise of cooperation in informal bodies comprised both of global powerhouses in the $\mathrm{G} 20$ and developing power centres in the BRICS. It illustrates the similarities in the drivers of cooperation in these developments, as well as the similar challenges these bodies have confronted in recent years.

The EU, the G20 and the BRICS mark, each in their own way, a changing world order in which states cooperate ever more closely in order to tackle transnational challenges.

The EU was founded on the idea that cooperation could prevent European nations from finding themselves at war again. EU cooperation deepened thereafter from the European Coal and Steel Community (ECSC) with an original membership of six states and a focus on "making war not only unthinkable but also materially impossible" [Schuman, 1950], to an integrated Union of 28 states, although after the Brexit vote in the United Kingdom, the UK is expected to leave the EU in 2019. Due to the varying speeds at which integration took place in different issue fields, the EU has been granted exclusive competences in some areas but not in others; the most spectacular cases are trade policy, which has made the EU the world's largest trading bloc with the European Commission as a single negotiator, and monetary policy, resulting in $19 \mathrm{EU}$ members sharing the euro as their common currency.

The G20 was created in order to address a different challenge. It emerged at the end of the 1990s in order to promote informal dialogue among 20 systemically important economies on a wide range of economic and financial issues [Kirton, 2013]. More specifically, the G20 was established as a forum of finance ministers and central bank governors in order to combat the Asian financial crisis. It was elevated to the level of heads of state and government in 2008 in response to the financial crisis which had broken out in the U.S. and Europe [Wouters, Van Kerckhoven, 2011]. ${ }^{2}$ Equally important, the G20 aims to enhance cooperation between its members in order "to achieve stable and sustainable world economic growth that benefits all" [G20, 2008].

A related informal body that brings together a handful of the G20 members in a different setting is the BRICS grouping of Brazil, Russia, India, China and South Africa. In 2009, the leaders of these emerging economies (excluding South Africa) gathered together in Yekaterinburg and held the first BRIC summit. The goal was to discuss proposals to improve the state of the global economy, reform of financial institutions and to foster cooperation and coordination between emerging economies in the future. In 2010, after the entry of South Africa, the grouping was renamed for the third summit to BRICS. The BRICS has discussed an increasing variety of topics; its summit declarations clearly demonstrate that the agenda has continuously grown with new issues included every year. The group "has evolved its global governance functions, moving from its focus on deliberation to direction-setting, decision-making, delivery and the development of BRICS governance institutions" [Larionova, Kirton, 2012]. Their most remarkable achievement so far is the foundation of the New Development Bank (NDB) which can be considered a partial alternative to the World Bank and the IMF (for more on this, see Lesage et al., 2013; Wouters, Van Kerckhoven, 2013). So far, there have been nine annual

${ }^{2}$ The Group of Twenty: A History. Available at: http://www.g20.utoronto.ca/docs/g20history.pdf (accessed 25 May 2018). 
BRICS summits. As the BRICS gathers together the most important emerging economies, its summits carry a certain weight.

However different they are, the EU, the G20 and the BRICS thus have a shared ambition. They all aim to promote coordination and steer decision-making. The EU, through its institutions, clearly steers the policies of its members. The G20 and the BRICS are also increasingly steering the actions of their members. Consequently, these bodies can be considered steering groups, although the EU is of course much more than that (more on this in Wouters and Van Kerckhoven [2017a]).

The EU, the G20 and the BRICS have been shaped by the challenges they have historically encountered. Most importantly, the 2008 global financial crisis resulted in significant changes for all three. Since then, the G20 has been elevated to become - as stated in the declaration of the Pittsburgh summit in September 2009 - the "premier forum for international economic cooperation." Around the same time, beginning on 1 December 2009, the EU entered its "post-Lisbon" era in which it seeks to play an expanded role on the global stage and exert greater influence within international bodies. The financial and economic crisis, as well as the responses to it, was an important driver for the emergence of the BRICS. In other words, the financial and economic crisis gave greater momentum to all three bodies, highlighting the need for coordinated and cooperative responses. More recently, the EU, the G20 and the BRICS have faced new challenges as antiglobalism and nationalism have rendered integration and coordination contested and more problematic. The EU is tested by the decision of the UK to leave the Union and the rise of populist and nationalist political groupings in several of its members. The annexation of Crimea by Russia in March 2014 has divided the G20 into two groups, one condemning the annexation, ${ }^{3}$ and the other siding with Russia or at least unwilling to criticize it. Most of the BRICS members sided with Russia as often they challenge western liberal positions as a way to align themselves. As many of the BRICS members have been under Western domination for quite some time, its members are highly suspicious of claims that sovereignty can be trumped by so-called universal principles of the humanitarian and antiproliferation variety [Keck, 2014]. A further challenge is the election of Donald Trump as U.S. president. His election and his political points of view clearly indicate a more antiglobalist approach, whereby his "America first" foreign policy constrains global cooperation [Trump, 2011].

\section{The EU's Position Toward the G20}

Europe is well represented at G20 meetings. A unique characteristic of European representation at the G20 is that the EU itself is a member of the G20, which is not the case in most other international organizations and fora, with the World Trade Organization (WTO) being a notable exception. Moreover, several individual EU members have a seat at the table of the G20 - France, Germany, Italy and the United Kingdom.

The EU sees the G20 as a useful vehicle for promoting global cooperation [European Commission, 2009]. Starting in 2008, when the G20 was elevated to the level of heads of state and government, the Commission has pushed for increased global cooperation in order to address the flaws of the international financial system and to mitigate the fallout of the crisis. From the perspective of the EU, the G20 forms a venue in which the EU can try to persuade other countries to adopt similar regulatory reforms. This helps to solve the issue of negative externalities (beggar-thy-neighbour policies) and to prevent the outbreak of future crises. Moreover, the EU needs to align itself with world-wide policies as this makes its own response more

${ }^{3}$ There were calls to suspend Russia from the G20 meeting in Brisbane. This never happened, but Russia was suspended from the Group of 8 (G8) [Wouters, Van Kerckhoven, 2014, 2017b]. 
effective [European Commission, 2010]. The G20's process and decisions have a strong influence on decisions taken at the European level [Wouters, Van Kerckhoven, 2011b]. The EU has been one of the best "students" among the G20 members in following up on and implementing G20 decisions. This also allows the EU to move faster internally; when a regulatory issue is elevated to the G20 level and agreed there, opposition from EU members often becomes much more difficult. The EU and the G20 thus have the potential to further each other's agendas. Coordinating the response to the crisis through the G20 and its associated bodies, including the Financial Stability Board (FSB), has often benefited the EU, which has been able to successfully put many of its proposals on the G20's agenda. Because the EU also implements the commitments made at the G20, its voice within that body is further enhanced.

Moreover, the EU consistently refers to G20 commitments in its legislation and policy documents, demonstrating that it takes these commitments seriously [Wouters, Van Kerckhoven, Odermatt, 2013]. In some fields, such as banking regulation, the EU has been a frontrunner. In other areas, such as the regulation of over-the-counter (OTC) derivatives, the EU has lagged behind other G20 members in fulfilling its commitments. However, there is a more problematic side to the relationship between the EU and the G20. There is neither a policy nor legal basis regarding European external representation at the G20. Consequently, EU members at the G20 can deviate from the "agreed language" established in preparation for G20 summits in order to represent their national interests. Moreover, as the four largest EU members also have an individual seat at the G20 table they can override smaller EU members who are deprived of direct influence at the G20 and also have less ability to define the "agreed language." These issues have proven to be problematic as some EU members have at times stated divergent positions, as in the case of the UK. Indeed, cooperation between the UK and the other EU members who are also members of the G20 is no longer a given after the Brexit vote, a reality that became clear during the Group of $7(\mathrm{G} 7)$ foreign ministers meeting in Lucca on 11 April 2017. At this meeting, the UK proposed additional sanctions against Russia, but this proposal was resisted by Italy and Germany and failed to make it into the final communiqué. One of the open questions for the future is whether the UK will continue to play in line with the European bloc, or move closer toward its transatlantic partner(s). The fact that the other three EU members of the G20 delivered a joint declaration condemning the U.S.'s decision to leave the Paris Agreement without receiving support from UK Prime Minister Theresa May possibly illustrates some new tendencies.

Moschella and Quaglia [2016] have studied the issue of EU cohesiveness in the G20. Interestingly, they found that preference homogeneity was not a necessary condition for EU cohesiveness, and that medium levels of cohesiveness materialized even on issues and at times when the economic preferences of the large members were fundamentally different, provided that the issues under negotiation were not politically salient. Of course, this claim might not hold in a post-Brexit world.

Not only does the EU have to worry about internal cohesiveness to push its agenda forward, it also needs to consider the preferences of the G20's 15 non-EU members. These members do not always have the same priorities as the EU, so the latter needs to reach out to them. However, due to current events in international relations - the issues with Russia, the election of Donald Trump, Brexit - some EU leaders feel closer cooperation between EU members should be preferred over outreach to global partners. German Chancellor Merkel, for example, has noted that the EU should become a stronger block in light of Brexit and Trump's take on the Paris Agreement on Climate Change [Chase, 2017]. However, she continued to stress the need for the G20 as a useful instrument for global change. 
As noted, the G20's agenda has influenced the EU. The EU has also urged the G20 to take action with regard to pressing issues in global affairs. The EU has done so particularly when these issues had serious consequences or impact on the EU itself. For example, the EU urged the G20 to help with the influx of refugees into Europe. In this instance, the EU asked G20 leaders to increase their support in dealing with the 65 million refugees in the world [Valero, 2016]. The EU also called upon the G20 to explore a global financial transactions tax [Reuters, 2010], to continue working on climate change (by, for example, urging other G20 countries to make their climate goals public [AP, 2015]), and to undertake actions with regard to terrorist threats [Unian, 2015].

\section{The EU's Position Toward the BRICS}

While no EU states are members of the BRICS, several of the BRICS members are important to Europe due to the integration of their economies with European economies, as well as their growing political clout. Clearly, the BRICS has been realizing impressive growth numbers, in particular with regard to trade and investment, and its members have gotten back on their feet much quicker than the other G20 members after the 2008 financial and economic crisis [Wouters, Van Kerckhoven, 2017c]. For example, with regard to trade it has been found that the EU plays a more important role in BRICS trade than vice versa, and that the EU has trade deficits with all BRICS members except India. With regard to foreign direct investment (FDI), the EU is among the main investors in each of the BRICS countries and the dominant investor in Brazil and Russia. According to Eurostat, the EU provided on average 53\% and 57\% of the FDI inflows in Brazil and Russia, respectively (2004-2007 average) [European Commission, 2014]. Knowledge ties between each of the BRICS countries and the EU have become stronger. The impressive pace of economic growth in China, and to a lesser extent in India, has resulted in an increase in their relative importance with respect to the EU, in turn outpacing the traditional privileged position of Russia [European Commission, 2014]. This reinforces their economic and political power, and makes them important partners for the EU if it is to continue playing a global role. The BRICS is playing an increasingly important role at the global level. It has become a hub for trade and even development.

Reflecting on the major differences between the five BRICS members, the intensification of their relations does not mean that they systematically form a bloc. It is debatable whether the BRICS countries have anything more in common than their size and economic potential. The structures of the five economies are very different, with Brazil and South Africa specializing in agriculture, Russia in commodities, India in services and China in manufacturing. At the same time, the BRICS members are in competition with each other to maintain high growth numbers. However, they share a similar ambition, namely to promote the G20 and other new multilateral settings as international fora and to counter what they perceive to be an undemocratic and unjust multilateral order dominated by the West [Freire, 2017].

The EU still has to come to grips with dealing more closely with the BRICS (see section 6). EU documents do not mention the BRICS as such, although they do address individual BRICS members. Conversely, BRICS summit declarations do not pay attention to the EU. An interesting development in this respect is that the last BRICS summit in Xiamen focused on BRICS+. The Chinese host took the initiative to also invite Mexico, Egypt, the president of the African Union, Equatorial Guinea, the president of the Group of 77, Thailand and Tajikistan. Interestingly, the BRICS reached out to Europe as well. On 12 September 2016, the embassies of BRICS countries in Brussels organized a conference on the global role of the BRICS. Moreover, the Director General for Bilateral Affairs of Belgium's Foreign Ministry publicly 
suggested inviting the EU to future BRICS gatherings [Jing, 2017]. However, the EU has until recently considered the BRICS countries to be unable to act together on any major global issue. This might partly explain the lack of a grand EU strategy. However, the establishment of the NDB and the increasing cooperation between the BRICS might alter this view.

\section{How the G20 and the BRICS Challenge the EU's Approach of Effective Multilateralism}

The EU has a particular approach with regard to its conduct in international affairs. As its international actions are guided by Article 21 of the Treaty on European Union, they should be based on core principles of the Union such as democracy, the rule of law, the universality and indivisibility of human rights and fundamental freedoms, and respect for the principles of the United Nations Charter and international law. As stated in the same article, the EU seeks to develop relations and build partnerships with third countries and international, regional or global organizations that share these principles.

This position on multilateralism often goes hand in hand with a focus on rules. The EU's doctrine of "effective multilateralism" leads to the EU favouring legally binding commitments and strong international regimes. These legally binding outcomes and their instruments should not only cover economic policies but also related domains such as environmental and social policy. At the same time, the EU's commitment to promoting the aforementioned principles implies that, from its perspective, these principles are not seen not as breaching national sovereignty but rather as prerequisites for sustainable cooperation [Wouters et al., 2012]. The G20 and the BRICS do not necessarily abide by the EU's multilateral approach - to some extent they even challenge it.

This observation warrants a closer look at how the G20 challenges the EU approach. In the European understanding, the legitimacy of the G20 rests on its contribution to fostering global public goods such as sustainable and inclusive growth, open trade, socioeconomic progress and protection of the environment and climate. This belief is reinforced by the multiple side fora surrounding G20 summits that engage a wide variety of non-state actors such as businesses, women's groups, scientific establishments, youth associations, think tanks and more. These are often applauded for providing analyses and recommendations to the main summit and fit closely with the EU's view of how global governance should work. ${ }^{4}$ But in the eyes of many other large players participating in the club, the G20 is not about legitimacy, but power. For them, the raison d'être of the G20 is probably not to reach agreements on some common good. Rather, it is just another platform for great power interests and preferences, balancing competing claims and ambitions, and focused on extracting concessions from other participants [European Council of Foreign Relations, 2017]. The position of several G20 members is therefore not exactly in line with the EU approach.

This is even more apparent among the emerging economies present at the G20 which have gathered in the BRICS. The BRICS members do sometimes rally around anti-Western claims, but they are not defined by this policy stance. Their greatest ambition is to realize a more inclusive and just international order that challenges the dominance of western neoliberalism. In contrast, members of the BRICS have also shown a willingness to integrate and recognize the current international order provided they are given a fair position within it [Freire, 2017]. Due to their recent rise in economic and political power, the BRICS members perceive themselves as increasingly on par with other global powers and want to see this acknowledged.

\footnotetext{
${ }^{4}$ In this sense, the G20 developed much faster than the G7.
} 
At the same time, they support multilateralism - but a version based on fundamentally different principles. Presumably encouraged by their recent success, they prioritize economic growth and development and are reluctant to let the economy be restricted by concerns that Europeans consider important, such as the environment, social protection or human rights. At the same time, and no doubt due to the history of colonization that some BRICS members share, they are wary of an overarching organization with strong decision-making powers. They prefer decision-making by consensus, voluntary commitments and respect for national sovereignty (see their decision to side with Russia over Crimea, for example). The BRICS is guided by "relational multilateralism," a concept that builds on a preference for consensual decision-making, voluntary engagement, a realist perspective on sovereignty and the absence of legally binding commitments. Relational governance emphasizes the governance of relationships between actors; it is process-oriented, with the process considered a collection of ongoing complex relations [Qin, 2011]. This relations-oriented form of multilateralism is often more attractive to developing countries since it focuses primarily on economic growth without the commitments that come with the European approach of effective multilateralism and fundamental values.

Relationship-based multilateralism, with its focus on consensus and coordination rather than developing fixed rules, has proven to be rather successful as well. It has been able to inform and change national policies, and has also had an impact on the global scale where it allowed the BRICS countries to coordinate positions in order to challenge the voting shares in the traditional Bretton Woods organizations [Keukeleire, Hooijmaaijers, 2014]. Another example is the 2009 Copenhagen Conference on Climate Change. Over the months preceding the conference, the EU met with several of its "strategic partners." The joint declarations after these meetings gave the impression that the EU and its partners were working toward finding common ground, despite their diverging approaches. But, during the Copenhagen conference, the strategic partners completely sidelined the EU and its position on the future of the climate change regime [Keukeleire, Bruyninckx, 2011]. Noteworthy in this respect is that in Copenhagen, the BRICS was replaced by the BASIC grouping of Brazil, South Africa, India and China which fought for higher carbon emissions allowances. Russia sat with the Europeans, quietly supporting the Kyoto Protocol, which allows Russia to sell significant emission rights due to the fact that greater industrial efficiency ensures that Soviet-era carbon emissions levels will not be reached in the future. This again shows that the BRICS is not always a strong, unified bloc.

\section{The Need for a Revised EU Strategy to Deal with International Informal Bodies}

For quite a while the EU did not have a real strategy to deal with informal bodies such as the G20 and the BRICS. At the same time, the rise of both these fora challenged the EU's effective multilateralism approach. This section investigates to what extent the EU's current global strategy allows the EU to more appropriately deal with the G20/BRICS.

\section{EU Global Strategy}

The EU Global Strategy on Foreign and Security Policy adopted in June 2016, entitled "Shared Vision, Common Action: A Stronger Europe," lays out the EU's approach as an international actor. The global strategy reiterates and reinforces the EU's defence of a liberal rulesbased order, with more pragmatic nuances [Larik, 2017].

However, the strategy does not pay much attention to the rise of informal bodies such as the G20 and the BRICS. The document mentions the G20 once, and only in passing. It notes 
that "on humanitarian action, sustainable development and climate change, the EU will partner with the UN and the G20" [European Union, 2016, p. 43]. The strategy does not include any substantive statements regarding the G20, even with respect to economic decision-making. The same holds true for the BRICS. BRICS summitry is not mentioned as such, although some BRICS members are. With regard to Russia, it is condemned for its breach of international law with the annexation of Crimea, but managing the EU-Russia relationship is deemed a key strategic challenge such that the EU will engage with Russia to discuss disagreements and cooperate if and when interests overlap [Ibid., p. 33]. As for China, the document states that the EU will engage China based on respect for rule of law, both domestically and internationally [Ibid., p. 37]. It further states that the EU will engage with China and India when it comes to fostering trade and maritime security [Ibid., pp. 38-41]. Brazil and South Africa, however, are not mentioned. In short, the EU's global strategy completely fails to address the rising importance of the G20, the BRICS and the emerging economies.

\section{Strategic Partnerships}

The EU has also pursued strategic partnerships with BRICS members. The preference for bilateral partnerships can partly be explained by the particular institutional setup of the EU. Each EU member retains decision-making authority in foreign policy, security and defence. This means that, whereas trade agreements follow commonly agreed-upon rules and procedures, political decisions about international relations and EU engagement with the BRICS/ G20 are the result of a consensus forged among EU members regarding a strategic approach.

With regard to the G20, the EU has introduced strategic partnerships with the nonEuropean G20 members with the exception of Argentina, with whom negotiations are carried out in the context of the EU-Mercosur Agreement, and Saudi Arabia, with whom negotiations are carried out in the context of the Cooperation Council for the Arab States of the Gulf.

The issues with the institutional setup of the EU are most obvious when dealing with the BRICS. Various EU members have differing views and policy preferences when dealing with BRICS members. Some members share a border with Russia and are dependent on Russia for their energy, thus making an EU strategy to deal with Russia extremely important for these countries. Moreover, some members have little interest in developing a detailed and encompassing strategy toward Brazil or South Africa as these countries may not appear be interesting counterparts at the moment, and uncertainty remains regarding their future prospects.

Since 2003, when the European Security Strategy (ESS) - the predecessor to the 2016 EU Global Strategy on Foreign and Security Policy - was adopted, the EU entered into strategic partnerships with all of the current BRICS countries, starting with China and Russia in 2003, followed by India in 2004 and Brazil and South Africa in 2007. In doing so, the Union displayed its desire to further cooperate with individual BRICS countries on key global challenges. These strategic partnerships are defined by the EU as building blocks of an effective multilateral order, with the UN at its apex [European Council, 2008]. In general, the formal relations with these five emerging countries follow the same pattern, although it may be more accurate to speak about "differentiated strategic partnerships" (see the overview in Sautenet [2012]). The partnerships include trade but encompass other issues such as energy, global warming and foreign and security policies. They also result in annual summits (or in the case of Russia, biannual summits), ministerial meetings as well as sectoral dialogues between EU officials and representatives of these third countries [Keukeleire, Hooijmaaijers, 2014]. However, the strategic partnerships of the EU with Brazil, China, India, Russia and South Africa have not helped to 
overcome divergences of views and interests between the EU and these emerging powers [Renard, Biscop, 2012].

The question arises whether the EU's approach should only consist of bilateral partnerships with the different BRICS members, or whether it should also work toward a consistent approach to the BRICS as a group. As indicated before, the 2009 Copenhagen Conference on Climate Change saw the EU sidelined, making the EU more aware of the bargaining power of the BRICS. In 2011, a joint reflection paper by the European External Action Service and the Commission, "Towards a Strengthened and Renewed EU Climate Diplomacy," was the first official document to draw attention to the bargaining power of the BRICS bloc in this field. Interestingly, there have been calls for a more structured relationship between the EU and the BRICS. Thus, the European parliament adopted on 20 December 2011 a resolution on the foreign policy toward the BRICS and other emerging powers. This resolution, entitled "EU Foreign Policy Towards the BRICS and Other Emerging Powers: Objectives and Strategies," stresses the need for multilateral governance and increased cooperation between the BRICS and the EU.

However, for the time being a bilateral approach appears to be the main modus operandi for EU-BRICS relations. This was exemplified in the February 2012 speech by then-HR/VP Catherine Ashton on EU foreign policy toward the BRICS [2012] which sent a very clear message: the EU must treat the BRICS as individual countries through the respective strategic partnerships.

\section{The Need for a Fully-Fledged Strategy}

Clearly, there is a case for developing a more comprehensive strategy for the EU to deal with both the G20 and the BRICS.

With respect to G20 members, a deeper strategy might be less of an issue. Due to the fact that the EU and several of its members are present at the G20, the EU clearly can steer some of the discussions and has an impact on the proceedings of the G20. Moreover, as argued previously, the EU and its members work toward agreed language in anticipation of the G20 summits. A stand-alone strategy is thus less of an issue since the EU can adapt to the agenda and has a strong influence in the proceedings.

As to the BRICS, the EU has not yet formulated a policy to respond to the BRICS' growing influence and assertiveness. This merits further exploration; the agendas of the EU and the BRICS have common goals, such as improved economic relations, increased development and the creation of a more stable and secure international environment. At the same time, it can be argued that whereas the EU aspires to become a global actor (as stated in its global strategy), the BRICS members have - despite their diversity - already achieved global reach in terms of geography, nature and economic size [Freire, 2017]. In light of the overall common agenda and the potential for the BRICS to help the EU achieve its goals, a more coherent approach toward the BRICS is needed.

\section{Concluding Remarks}

This article critically reviewed how the EU has dealt with the rise of informal bodies such as the G20 and the BRICS. Both bodies have surfaced in recent years as steering groups in the global economy. Compared to formal international organizations, they are characterized by a more informal structure and a lack of legally binding decisions. The EU has been an active member in 
the G20 since the latter's establishment. With regard to the BRICS, the EU is one of the most important partners for the emerging economies represented in this forum.

The rise of informal club-like bodies such as the G20 and the BRICS challenges the EU's approach to the global order, rooted in effective multilateralism. The EU is in favour of a rulesbased approach toward international bodies with respect for European core values, including issues such as the rule of law and human rights. Crucially, this approach is not shared by some of the EU's fellow G20 members, in particular those G20 members that make up the BRICS. Nonetheless, the EU has developed a strategic partnership with each of these countries. However, these partnerships are purely bilateral, and a strategy for the EU to deal with the rise of informal summitry is missing. This is exemplified by the EU's 2016 global strategy document, which only mentions the G20 once.

Seeing the particular challenges these bodies pose, a fully fledged EU strategy toward the G20 and the BRICS should be developed. This might be particularly important for the Union's relations with the BRICS, which is no longer a loose grouping of emerging economies. Since the EU is not represented in the BRICS, and since both share certain ambitions, closer cooperation could be extremely valuable. The development of a strategy to deal with these bodies could also ensure that the EU is better able to push forward its core values at the global level.

\section{References}

AP (2015) EU Urges G20 Countries to Make Climate Goals Public. 20 August. Available at: https://www. apnews.com/aeafa43e9aa94bedab05f2dd0736cceb (accessed 25 May 2018).

Ashton C. (2012) Speech on EU Foreign Policy Towards the BRICS and Other Emerging Powers. Speech 12/56. 1 February. Available at: europa.eu/rapid/press-release_SPEECH-12-56_en.pdf (accessed 25 May 2018).

Chase J. (2017) G20: Angela Merkel Sketches Vision of French and German-led Europe. Deutsche Welle. 29 June. Available at: http://www.dw.com/en/g20-angela-merkel-sketches-vision-of-french-and-german-ledeurope/a-39469089 (accessed 25 May 2018).

Cooper R.N. (1968) The Economics of Interdependence: Economic Policy in the Atlantic Community. New York: McGraw-Hill.

European Commission (2009) Economic Crisis in Europe: Causes, Consequences and Responses. European Economy, no 7.

European Commission (2010) Communication: From Financial Crisis to Recovery: A European Framework for Action (OJ 2010 C76/28).

European Commission (2014) EU and BRICS: Challenges and Opportunities for European Competitiveness and Cooperation. Industrial Policy and Economic Reform Paper, no 13.

European Council (2008) Report on the Implementation of the European Security Strategy: Providing Security in a Changing World. Brussels: European Union.

European Council of Foreign Relations (2017) The Hamburg G20: A Clash of Competing Visions of World Affairs. Available at: http://www.ecfr.eu/article/commentary_the_hamburg_g20_a_clash_of_competing_visions_of_world_7209 (accessed 25 May 2018).

European Union (2016) Shared Vision, Common Action: A Stronger Europe - A Global Strategy on the European Union's Foreign and Security Policy.

Freire M.R. (2017) EU Relations with the BRICS: Strategic Partnership or Structural Disjunction? International Organisations Research Journal, vol. 12, no 3, pp. 182-200. (In Russian and English.) DOI: 10.17323/19967845-2017-03-182.

G20 (2008) Declaration on the Summit of Financial Markets and the World Economy. Washington DC, 15 November. 
Jing Fu (2017) Brussels Foreign Affairs Head Calls for EU Presence at BRICS Meetings. China Daily. 12 September. Available at: http://www.chinadaily.com.cn/world/2017-09/12/content_31870182.htm (accessed 25 May 2018).

Keck Z. (2014) Why Did BRICS Back Russia on Crimea? The Diplomat, 31 March.

Keukeleire S., Bruyninckx H. (2011) The European Union, the BRICS, and the Emerging New World Order. International Relations and the European Union (C. Hill, M. Smith (eds)). Oxford University Press. Second Edition.

Keukeleire S., Hooijmaaijers B. (2014) The BRICS and Other Emerging Power Alliances and Multilateral Organizations in the Asia-Pacific and the Global South: Challenges for the European Union and Its View on Multilateralism. Journal of Common Market Studies, vol. 52, no 3, pp. 582-599.

Kirton J. (2013) G20 Governance for a Globalized World. Ashgate.

Lake D.A. (2006) International Political Economy: A Maturing Discipline. The Oxford Handbook of Political Economy (B.R. Weingast, D.A. Wittman (eds)). Oxford: Oxford University Press, pp. 757-778.

Larik J. (2017) The EU's Global Strategy in the Age of Brexit and 'America First.' Leuven Centre for Global Governance Studies Working Paper, no 193.

Larionova M., Kirton J. (2012) From Reform to Crisis Response: Addressing the Key Global Issues. BRICS: The 2012 New Delhi Summit. Available at https://papers.ssrn.com/sol3/papers.cfm?abstract_id=2335358 (accessed 25 May 2018).

Lesage D., Debaere P., Dierckx S., Vermeiren M. (2013) IMF Reform After the Crisis. International Politics, vol. 50, no 4, pp. 553-578.

Moschella M., Quaglia L. (2016) To Agree or Not to Agree? Explaining the Cohesiveness of the European Union in the Group of Twenty. Journal of European Public Policy, vol. 23, no 6, pp. 906-924.

Qin Y. (2011) Rule, Rules and Relations: Towards a Synthetic Approach to Governance. Chinese Journal of International Politics, vol. 4, no 2, pp. 117-145.

Renard T., Biscop S. (eds) (2012) The EU and Emerging Powers in the 21st Century: How Europe Can Shape a New Global Order. Ashgate.

Reuters (2010) EU Urges G20 to Explore Global Transaction Tax. 23 June. Available at: https://www.reuters. com/article/us-eu-g20-letter/eu-urges-g20-to-explore-global-transaction-tax-idUKTRE65M1DZ20100623 (accessed 25 May 2018).

Sautenet A. (2012) The EU's Strategic Partnerships with Emerging Powers: Institutional, Legal, Economic and Political Perspectives. The EU and Emerging Powers in the 21st Century: How Europe Can Shape a New Global $\operatorname{Order}$ (T. Renard, S. Biscop (eds)). Ashgate, pp. 123-146.

Schuman R. (1950) The Schuman Declaration - 9 May 1950. Available at https://europa.eu/european-union/ about-eu/symbols/europe-day/schuman-declaration_en (accessed 25 May 2018).

Trump D.J. (2011) Time to Get Though: Make America Great Again. Regnery Publishing.

Unian (2015) EU Urges G20 to Respond to Terrorist Threat - Tusk. 14 November. Available at: https://www. unian.info/world/1183514-eu-urges-g20-to-respond-to-terrorist-threat-tusk.html (accessed 25 May 2018).

Valero J. (2016) Europe Urges G20 Nations to Pour Billions into Refugee Crisis. Euractiv. 4 September. Available at: https://www.euractiv.com/section/global-europe/news/europe-urges-g20-nations-to-pour-billionsinto-refugee-crisis/ (accessed 25 May 2018).

Van Kerckhoven S., Crombez C. (2015) Global Economic Governance and the Emergence of the G20. Global Governance and Democracy: A Multidisciplinary Analysis (J. Wouters, A. Braeckman, M. Lievens, E. Bécault (eds)). Edward Elgar, pp. 97-116.

Wouters J., Van Kerckhoven S. (2011) The OECD and the G20: An Ever Closer Relationship? George Washington International Law Review, vol. 43, no 2, pp. 345-374.

Wouters J., Van Kerckhoven S. (2011b) The EU's Internal and External Regulatory Actions after the Outbreak of the 2008 Financial Crisis. European Company Law, vol. 8, no 5, pp. 201-207. 
Wouters J., Bruyninckx H., Basu S., Schunz S. (eds) (2012) The European Union and Multilateral Governance: Assessing EU Participation in United Nations Human Rights and Environmental Fora. Basingstoke: Palgrave Macmillan.

Wouters J., Van Kerckhoven S. (2013) The International Monetary Fund. Handbook on the EU and International Institutions: Performance, Policy, Power (K.E. Jorgensen, K. Laatikainen (eds)). London: Routledge, pp. 221-233.

Wouters J., Van Kerckhoven S., Odermatt J. (2013) The EU at the G20 and the G20's Impact on the EU. The EU's Role in Global Governance: The Legal Dimension (B. Van Vooren, S. Blockmans, J. Wouters (eds)). Oxford University Press, pp. 259-272.

Wouters J., Van Kerckhoven S. (2014) Gx Summitry at Crossroads. Diplomatist, vol. 2, no 7, pp. 10-12.

Wouters J., Van Kerckhoven S. (2017a) The Gx and Democracy in Multilateral Governance. Studia Diplomatica, vol. 68, no 3, pp. 45-65.

Wouters J., Van Kerckhoven S. (2017b) Preserving Consensus. G7 Italy: The Taormina Summit. The G7 Research Group, Munk School of Global Affairs, University of Toronto, pp. 120-121.

Wouters J., Van Kerckhoven S. (2017c) The G20 and the BRICS on Trade and Investment: Trends and Policies. International Organisations Research Journal, vol. 12, no 3, pp. 7-31 (in Russian and English). DOI: 10.17323/1996-7845-2017-03-7. 


\title{
Перспективы взаимодействия ЕС с «Группой двадцати» и БРИКС ${ }^{1}$
}

\author{
Я. Ваутерс, С. Ван Керкховен
}

Ваутерс Ян - доктор философии, профессор, штатный профессор по международному праву и международным организациям, директор Лёвенского центра исследований в области глобального управления и Института международного права при Лёвенском католическом университете; House De Dorlodot, Deberiotstraat 34 B-3000 Leuven, Belgium; E-mail: jan.wouters@ggs.kuleuven.be

Ван Керкховен Свен - доктор философии, декан факультета бизнеса и экономики в Везалийском колледже при Брюссельском свободном университете, научный сотрудник Лёвенского центра исследований в области глобального управления и факультета экономики и бизнеса при Лёвенском католическом университете; Pleinlaan 5, 1050 Brussels, Belgium; E-mail: Sven.Van.Kerckhoven@vub.be

В статье рассматривается взаимодействие Европейского союза (ЕC) как наиболее развитой региональной организации и одного из сильнейших игроков мировой экономики с институтами «клубного» типа, такими как «Группа двадцати» и БРИКС. ЕС, «Группа двадцати» и БРИКС имеют схожие амбиции - все они стремятся решать глобальные (или региональные) трансграничные проблемы путем расширения сотрудничества и координации на международном уровне. Несмотря на то что ЕС является сторонником развития глобальных директивных органов, развитие неформальных органов управления ставит под сомнение подход ЕС к глобальному управлению, который в значительной степени опирается на эффективный многосторонний подход и использование правил. Поскольку некоторые из членов БРИКС и «Группы двадиати» поддерживают подход, основанный на отношениях, ориентированных на консенсус и координацию, эти неформальные организации бросают вызов европейскому подходу. Требуется четкая европейская стратегия взаимодействия с неформальными организациями. В настоящее время у ЕС нет согласованного и последовательного подхода к решению данного вопроса. Об этом свидетельствует отсутствие каких-либо ссылок на БРИКС и лишь поверхностное упоминание «руппы двадиати» в глобальной стратегии ЕС 2016 г., а также тот факт, что ЕС в настоящее время имеет только двусторонние стратегические партнерские отношения с большинством членов «Группы двадиати» и БРИКС. Авторы утверждают, что ЕС следует разработать полноценную стратегию в отношении «Группы двадцати» и БРИКС, учитывая особый характер проблем, стоящих перед этими организациями и их заметное укрепление в последние годы.

Ключевые слова: ЕС; «Группа двадцати»; БРИКС; глобальное управление

Для цитирования: Ваутерс Я., Ван Керкховен С. (2018) Перспективы взаимодействия ЕС с «Группой двадцати» и БРИКС // Вестник международных организаций. Т. 13. № 2. С. 60-75. DOI: 10.17323/1996-78452018-02-04.

\section{Источники}

AP (2015) EU Urges G20 Countries to Make Climate Goals Public. 20 August. Режим доступа: https://www. apnews.com/aeafa43e9aa94bedab05f2dd0736cceb (дата обращения: 25.05.2018).

Ashton C. (2012) Speech on EU Foreign Policy Towards the BRICS and Other Emerging Powers. Speech 12/56. 1 February. Режим доступа: europa.eu/rapid/press-release_SPEECH-12-56_en.pdf (дата обращения: 25.05.2018).

\footnotetext{
${ }^{1}$ Статья поступила в редакцию в феврале 2018 г.
} 
Chase J. (2017) G20: Angela Merkel Sketches Vision of French and German-led Europe. Deutsche Welle. 29 June. Режим доступа: http://www.dw.com/en/g20-angela-merkel-sketches-vision-of-french-and-german-led-europe/a-39469089 (дата обращения: 25.05.2018).

Cooper R.N. (1968) The Economics of Interdependence: Economic Policy in the Atlantic Community. New York: McGraw-Hill.

European Commission (2009) Economic Crisis in Europe: Causes, Consequences and Responses. European Economy. No. 7.

European Commission (2010) Communication: From Financial Crisis to Recovery: A European Framework for Action (OJ 2010 C76/28).

European Commission (2014) EU and BRICS: Challenges and Opportunities for European Competitiveness and Cooperation. Industrial Policy and Economic Reform Paper. No. 13.

European Council (2008) Report on the Implementation of the European Security Strategy: Providing Security in a Changing World. Brussels: European Union.

European Council of Foreign Relations (2017) The Hamburg G20: A Clash of Competing Visions of World Affairs. Режим доступа: http://www.ecfr.eu/article/commentary_the_hamburg_g20_a_clash_of_competing_visions_of_world_7209 (дата обращения: 25.05.2018).

European Union (2016) Shared Vision, Common Action: A Stronger Europe - A Global Strategy on the European Union's Foreign and Security Policy.

Freire M.R. (2017) EU Relations with the BRICS: Strategic Partnership or Structural Disjunction? // International Organisations Research Journal. Vol. 13. No. 3. P. 182-200. (In Russian and English.) DOI: 10.17323/1996-7845-2017-03-182.

G20 (2008) Declaration on the Summit of Financial Markets and the World Economy. Washington DC, 15 November.

Jing Fu (2017) Brussels Foreign Affairs Head Calls for EU Presence at BRICS Meetings. China Daily. 12 September. Режим доступа: http://www.chinadaily.com.cn/world/2017-09/12/content_31870182.htm (дата обращения: 25.05.2018).

Keck Z. (2014) Why Did BRICS Back Russia on Crimea? // The Diplomat. 31 March.

Keukeleire S., Bruyninckx H. (2011) The European Union, the BRICS, and the Emerging New World Order // International Relations and the European Union / C. Hill, M. Smith (eds). Oxford University Press. Second Edition.

Keukeleire S., Hooijmaaijers B. (2014) The BRICS and Other Emerging Power Alliances and Multilateral Organizations in the Asia-Pacific and the Global South: Challenges for the European Union and Its View on Multilateralism // Journal of Common Market Studies. Vol. 52. No 3. P. 582-599.

Kirton J. (2013) G20 Governance for a Globalized World. Ashgate.

Lake D.A. (2006) International Political Economy: A Maturing Discipline // The Oxford Handbook of Political Economy / B.R. Weingast, D.A. Wittman (eds). Oxford: Oxford University Press. P. 757-778.

Larik J. (2017) The EU's Global Strategy in the Age of Brexit and 'America First.' Leuven Centre for Global Governance Studies Working Paper. No. 193.

Larionova M., Kirton, J. (2012) From Reform to Crisis Response: Addressing the Key Global Issues. BRICS: The 2012 New Delhi Summit. Режим доступа: https://papers.ssrn.com/sol3/papers.cfm?abstract_ $\mathrm{id}=2335358$ (дата обращения: 25.05.2018).

Lesage D., Debaere P., Dierckx S., Vermeiren M. (2013) IMF Reform After the Crisis // International Politics. Vol. 50. No. 4. P. 553-578.

Moschella M., Quaglia L. (2016) To Agree or Not to Agree? Explaining the Cohesiveness of the European Union in the Group of Twenty // Journal of European Public Policy. Vol. 23. No. 6. P. 906-924.

Qin Y. (2011) Rule, Rules and Relations: Towards a Synthetic Approach to Governance // Chinese Journal of International Politics. Vol. 4. No. 2. P. 117-145. 
Renard T., Biscop S. (eds) (2012) The EU and Emerging Powers in the 21st Century: How Europe Can Shape a New Global Order. Ashgate.

Reuters (2010) EU Urges G20 to Explore Global Transaction Tax. 23 June. Режим доступа: https://www. reuters.com/article/us-eu-g20-letter/eu-urges-g20-to-explore-global-transaction-tax-idUKTRE65M1DZ20100623 (дата обращения: 25.05.2018).

Sautenet A. (2012) The EU's Strategic Partnerships with Emerging Powers: Institutional, Legal, Economic and Political Perspectives // The EU and Emerging Powers in the 21st Century: How Europe Can Shape a New Global Order / T. Renard, S. Biscop (eds). Ashgate. P. 123-146.

Economic and Political Perspectives // The EU and Emerging Powers in the 21st Century: How Europe Can Shape a New Global Order / T. Renard, S. Biscop (eds). Ashgate. P. 123-146.

Schuman R. (1950) The Schuman Declaration - 9 Мау 1950. Режим доступа: https://europa.eu/europeanunion/about-eu/symbols/europe-day/schuman-declaration_en (дата обращения: 25.05.2018).

Trump D.J. (2011) Time to Get Though: Make America Great Again. Regnery Publishing.

Unian (2015) EU Urges G20 to Respond to Terrorist Threat - Tusk. 14 November. Режим доступа: https:// www.unian.info/world/1183514-eu-urges-g20-to-respond-to-terrorist-threat-tusk.html (дата обращения: 25.05.2018).

Valero J. (2016) Europe Urges G20 Nations to Pour Billions into Refugee Crisis. Euractiv. 4 September. Режим доступа: https://www.euractiv.com/section/global-europe/news/europe-urges-g20-nations-to-pour-billionsinto-refugee-crisis/ (дата обращения: 25.05.2018).

Van Kerckhoven S., Crombez C. (2015) Global Economic Governance and the Emergence of the G20 // Global Governance and Democracy: A Multidisciplinary Analysis / J. Wouters, A. Braeckman, M. Lievens, E. Bécault (eds). Edward Elgar. P. 97-116.

Wouters J., Van Kerckhoven S. (2011) The OECD and the G20: An Ever Closer Relationship? // George Washington International Law Review. Vol. 43. No 2. P. 345-374.

Wouters J., Van Kerckhoven S. (2011b) The EU's Internal and External Regulatory Actions after the Outbreak of the 2008 Financial Crisis // European Company Law. Vol. 8. No 5. P. 201-207.

Wouters J., Bruyninckx H., Basu S., Schunz S. (eds) (2012) The European Union and Multilateral Governance: Assessing EU Participation in United Nations Human Rights and Environmental Fora. Basingstoke: Palgrave Macmillan.

Wouters J., Van Kerckhoven S. (2013) The International Monetary Fund // Handbook on the EU and International Institutions: Performance, Policy, Power / K.E. Jorgensen, K. Laatikainen (eds). London: Routledge. P. 221-233.

Wouters J., Van Kerckhoven S., Odermatt J. (2013) The EU at the G20 and the G20's Impact on the EU // The EU's Role in Global Governance: The Legal Dimension / B. Van Vooren, S. Blockmans, J. Wouters (eds). Oxford University Press. P. 259-272.

Wouters J., Van Kerckhoven S. (2014) Gx Summitry at Crossroads // Diplomatist. Vol. 2. No. 7. P. 10-12.

Wouters J., Van Kerckhoven S. (2017a) The Gx and Democracy in Multilateral Governance // Studia Diplomatica. Vol. 68. No 3. P. 45-65.

Wouters J., Van Kerckhoven S. (2017b) Preserving Consensus // G7 Italy: The Taormina Summit. The G7 Research Group, Munk School of Global Affairs, University of Toronto. P. 120-121.

Wouters J., Van Kerckhoven S. (2017c) The G20 and the BRICS on Trade and Investment: Trends and Policies // International Organisations Research Journal. Vol. 12. No 3. P. 7-31. (In Russian and English.) DOI: 10.17323/1996-7845-2017-03-7. 